\title{
INCREASED SODIUM ION CONDUCTANCE THROUGH NICOTINIC ACETYLCHOLINE RECEPTOR CHANNELS IN PC12 CELLS EXPOSED TO NERVE GROWTH FACTORS ${ }^{1}$
}

\author{
CHRISTOPHER M. AMY² AND EDWARD L. BENNETT \\ Melvin Calvin Laboratory, Lawrence Berkeley Laboratory, University of California, Berkeley, California 94720
}

Received September 8, 1982; Revised February 25, 1983; Accepted March 3, 1983

\begin{abstract}
${ }^{22} \mathrm{Na}^{+}$uptake in response to cholinergic stimulation was measured in PC12 cells grown in media containing either $\beta$-nerve growth factor (NGF) from mouse submaxillary gland or a component of Bungarus multicinctus venom (fraction 9B) which has nerve growth factor activity. Our results showed that each of these nerve growth factors increased the $\mathrm{Na}^{+}$conductance capacity of $\mathrm{ACh}$ receptor-linked ion channels in PC12 cells. Compared to untreated cells, $\mathrm{Na}^{+}$uptake was enhanced by about $40 \%$ in cells exposed for 24 to $30 \mathrm{hr}$ to either $50 \mathrm{ng} / \mathrm{ml}$ of $\beta$-NGF or to $5 \mu \mathrm{g} / \mathrm{ml}$ of fraction $9 \mathrm{~B}$. 'This cholinergically stimulated $\mathrm{Na}^{+}$flux increased with time and reached a level 2 - to 3 -fold higher than that of untreated cells after 4 to 6 days' exposure to NGFs. The generation of neurites in response to NGFs from either source occurred with the same time course as the increase in $\mathrm{Na}^{+}$ channel conductance. Growth factor-enhanced $\mathrm{Na}^{+}$uptake remained for several days after NGFs were removed from cells and neurites were lost. $\mathrm{Na}^{+}$flux into untreated and into 9B-or $\beta$-NGFtreated cells was inhibited to a greater extent by a nicotinic than by a muscarinic antagonist. Dibutyryl cyclic AMP did not cause an increase in $\mathrm{Na}^{+}$uptake in response to cholinergic agonists at concentrations which stimulated neurite-like process formation, and dibutyryl cyclic AMP did not potentiate the effects of NGFs.
\end{abstract}

When PC12 pheochromocytoma cells in culture are exposed to nerve growth factor (NGF), these normally spherical, continuously dividing cells respond by extending neurites and by ceasing cell division within 1 week (Greene and Tischler, 1976). These changes are accompanied by an increase in the specific activities of choline acetyltransferase (Schubert et al., 1977), acetylcholinesterase (Greene and Rukenstein, 1981), and ornithine decarboxylase (Hatanaka et al., 1978) along with an increase in the synthesis of proteins (Garrels and Schubert, 1979) and RNA (Gunning et al., 1981a). Dichter et al. (1977) showed that NGF-induced changes in PC12 cells included an increased electrical excitability and sensitivity to acetylcholine compared to untreated cells. PC12 cells grown for more than 2 weeks with NGF showed an increased responsiveness to short pulses of iontophoretically applied acetylcholine compared to cells

\footnotetext{
This work was supported by National Institutes of Health Grant 16661 and by the Office of Energy Research, Office of Health and Environmental Research, Health Effects Research Division of the United States Department of Energy under Contract DE-AC0376SF00098. We wish to thank Dr. James Bartholomew for helpful discussions and for use of tissue culture facilities.

${ }^{2}$ To whom correspondence should be addressed.
}

grown in control medium. These changes are consistent with the view that NGF stimulates the differentiation of PC12 pheochromocytoma cells into neuron-like cells (Greene and Tischler, 1976).

The experiments reported here were designed to investigate how NGF affects the development of cholinergic sensitivity in PC12 cells. Patrick and Stallcup (1977a, b) assayed nicotinic acetylcholine receptor function by measuring the uptake of ${ }^{22} \mathrm{Na}^{+}$into PC12 cells in response to cholinergic stimulation. They showed that $\alpha$-bungarotoxin, which inhibits cholinergically stimulated $\mathrm{Na}^{+}$ion flux into muscle cells, did not inhibit $\mathrm{Na}^{+}$ ion uptake by PC12 cells. They concluded that $\alpha$-bungarotoxin did not bind to the nicotinic $\mathrm{ACh}$ receptor and that labeled toxin could, therefore, not be used to determine the number of ACh receptor sites on the surface of PC12 cells. We have used ${ }^{22} \mathrm{Na}^{+}$uptake in response to the cholinergic agonist carbamylcholine $(\mathrm{CCh})$ to measure the sensitivity of PC12 cells to cholinergic stimulation and, indirectly, as an indication of the number of ACh-sensitive ion channels on the surface of PC12 cells grown under different culture conditions. Our results showed that polypeptide nerve growth factors isolated from mouse submaxillary gland or from snake venom enhanced cholinergically mediated $\mathrm{Na}^{+}$uptake into PC12 
cells to the same extent but at different concentrations. This effect of nerve growth factor on $\mathrm{Na}^{+}$uptake through the ACh receptor-linked ion channel increased over approximately the same time period as did the outgrowth of neurites from PC12 cells.

\section{Materials and Methods}

Cell growth and growth factor treatment conditions. The PC12 clone of a rat pheochromocytoma cell line was obtained from the laboratory of Eric Shooter at Stanford University and grown in Dulbecco's modified Eagle's medium (GIBCO) containing $10 \%$ fetal calf serum and $5 \%$ horse serum. Cells were grown on polystyrene tissue culture dishes (Falcon) in a water-saturated atmosphere of $90 \%$ air $10 \% \mathrm{CO}_{2}$.

Nerve growth factors from two different sources were added to cultures of subconfluent cells to induce cellular differentiation characterized by neurite outgrowth. $\beta$ NGF from mouse submaxillary gland was obtained from the Technology Transfer Office of the State University of New York, Albany. Venom from the Formosan krait Bungarus multicinctus obtained from the Miami Serpentarium contained a component with nerve growth factor activity. Proteins in this crude venom were separated and purified by column chromatography on CM-Sephadex C50 and Sephadex G50 (Hanley et al., 1977). This procedure separated toxic venom components from a nontoxic protein (fraction 9B) which induced neurite outgrowth from chick ganglionic neurons (Hanley, 1978). Snake venom fraction 9B used in this study contained two protein components with molecular weights of approximately 10,000 to 14,000 when electrophoresed on $15 \%$ SDS polyacrylamide gels. Either $\beta$-NGF or fraction 9B was added to subconfluent cells in normal growth medium for the periods of time indicated for each experiment.

Neurite outgrowth was observed with a Nikon Diaphot-TMD inverted microscope with phase contrast optics, and the extent of neurite production was estimated using criteria developed by Gunning et al. (1981a). Since cells used for ${ }^{27} \mathrm{Na}^{+}$uptake assays were plated at very high density, it was not feasible to determine the actual percentage of neurite-bearing cells. Estimates of neurite outgrowth were, therefore, based on neurite production relative to maximum responses under optimal $\beta$-NGF treatment conditions.

Assay for ${ }^{22} \mathrm{Na}^{+}$uptake. Measurements of ${ }^{22} \mathrm{Na}^{+}$influx into PC12 cells were performed as described by Patrick and Stallcup (1977b). PC12 cells were resuspended in fresh growth medium with or without growth factor and plated on polylysine-coated 12 -well cluster dishes (Costar) at a concentration of 1 to $2 \times 10^{6}$ cells $/ \mathrm{ml}$ and $1 \mathrm{ml} /$ well $\left(4 \mathrm{~cm}^{2}\right.$ surface area) for $24 \mathrm{hr}$ prior to assay unless specified otherwise. Immediately before the assay, cells were washed briefly with assay buffer containing $130 \mathrm{~mm}$ $\mathrm{NaCl}, 5.4 \mathrm{mM} \mathrm{KCl}, 2 \mathrm{mM} \mathrm{CaCl}, 5 \mathrm{~mm}$ glucose, and 50 mM HEPES adjusted to $\mathrm{pH} 7.4$ with $\mathrm{NaOH}$. Assay buffer (300 $\mu$ l) supplemented with $5 \mathrm{mM}$ ouabain, $1.5 \mu \mathrm{Ci} / \mathrm{ml}$ of ${ }^{22} \mathrm{NaCl}$ (New England Nuclear), and agonist (carbamylcholine or nicotine) was then added to each well to initiate the assay. ${ }^{22} \mathrm{Na}^{+}$uptake was stopped by washing cells with three 2 -ml aliquots of wash buffer containing
$150 \mathrm{~mm} \mathrm{NaCl}, 5.4 \mathrm{~mm} \mathrm{KCl}, 2 \mathrm{mM} \mathrm{CaCl}_{2}, 5 \mathrm{~mm}$ glucose, and $5 \mathrm{~mm}$ HEPES buffer ( $\mathrm{pH}$ 7.4). Cells were dissolved in $1 \mathrm{ml}$ of $0.4 \mathrm{~N} \mathrm{NaOH}$, and the amount of ${ }^{22} \mathrm{Na}^{+}$taken up was determined by counting in a Tracor Analytic gamma counter. All values were normalized for protein content in each well determined by the method of Lowry et al. (1951); cells counted using a hemocytometer showed that there were approximately $240 \mu \mathrm{g}$ of protein $/ 10^{6}$ cells. In each experiment, ${ }^{22} \mathrm{Na}^{+}$uptake into identically treated cells assayed without agonist was subtracted to obtain net agonist-stimulated uptake. Preliminary studies showed that uptake was linear with time between 0 and $30 \mathrm{sec}$ in agreement with previous ${ }^{22} \mathrm{Na}^{+}$uptake studies with PC12 cells (Stallcup, 1979; Karpen et al., 1982); all assays were performed for $30 \mathrm{sec}$ at $22^{\circ} \mathrm{C}$.

The effects of cholinergic inhibitors on $\mathrm{Na}^{+}$uptake were tested by pre-incubating cells for $10 \mathrm{~min}$ in Prep medium (Dulbecco's modified Eagle's medium plus 1\% fetal calf serum and $5 \mathrm{mM}$ HEPES, pH 7.4) containing inhibitor (Patrick and Stallcup, 1977b) prior to assay for $\mathrm{Na}^{+}$uptake as described above.

Materials. Atropine and $d$-tubocurarine were obtained from Calbiochem. $N^{6}, O^{2 \prime}$-Dibutyryl adenosine $3^{\prime}: 5^{\prime}$ cyclic monophosphate (dbcAMP), nicotine, and carbamylcholine were from Sigma.

\section{Results}

Effects of NGFs on PC12 cell morphology. Neurite outgrowth from $\mathrm{PC} 12$ cells exposed to nerve growth factor increased with time and with increasing $\beta$-NGF concentrations. This response was maximal when cells were treated with $50 \mathrm{ng} / \mathrm{ml}$ of $\beta$-NGF for 4 to 6 days as described by Gunning et al. (1981a). Approximately the same level of neurite production was obtained by growing cells in medium containing $5 \mu \mathrm{g} / \mathrm{ml}$ of snake venom fraction $9 \mathrm{~B}$ for the same length of time. Morphological changes in response to $9 \mathrm{~B}$ treatment were indistinguishable from those of $\beta$-NGF-treated cells, but 100 -fold more $9 \mathrm{~B}$ was necessary to elicit the same response. Hanley (1978) also reported a 100-fold difference in the amount (by weight) of mouse submaxillary $\beta$-NGF and fraction 9B required to stimulate maximal neurite outgrowth from chick neuronal ganglia.

Effects of NGFs on CCh-stimulated $\mathrm{Na}^{+}$uptake. Our initial experiments were designed to determine whether both nerve growth factors increased ACh-stimulated $\mathrm{Na}^{+}$ uptake by PC12 cells and, if so, whether this increased $\mathrm{Na}^{+}$uptake could be inhibited by $\alpha$-bungarotoxin or other fractions from the venom of $B$. multicinctus which were lethal when injected into mice (Hanley et al., 1977). Table I presents data which showed that a week-long exposure of PC12 cells to the nontoxic snake venom fraction $9 \mathrm{~B}$ stimulated $\mathrm{Na}^{+}$uptake by cells assayed with the cholinergic agonist carbamylcholine. Under these growth conditions, neurite outgrowth was approximately equal to the maximum outgrowth with $\beta$-NGF. No increase in $\mathrm{Na}^{+}$flux was seen after treating previously untreated cells with $9 \mathrm{~B}$ for $1 \mathrm{hr}$ prior to assay. Also, a 1hr pre-incubation of cells grown in normal or growth factor-containing media had no effect on $\mathrm{Na}^{+}$flux in response to cholinergic agonists. When other pre- and postsynaptic toxins isolated from $B$. multicinctus venom 
TABLE I

Effect of $\alpha$-bungarotoxin and $9 B$ fractions on $\mathrm{CCh}$-stimulated $\mathrm{Na}^{+}$ uptake

PC1 2 cells were treated with $0.5 \mu \mathrm{g} / \mathrm{ml}$ of $9 \mathrm{~B}$ on day 0 and at 2-day intervals thereafter. On day 7 , untreated and 9B-treated cells were replated in fresh media with or without $9 \mathrm{~B}(0.5 \mu \mathrm{g} / \mathrm{ml})$ for ${ }^{22} \mathrm{Na}^{+}$flux assay the next day as described under "Materials and Methods." Prior to assay, the culture media were removed and the cells were preincubated with Prep medium containing no additions (control), $\alpha$ bungarotoxin $(\alpha-\mathrm{Bgt})(0.5 \mu \mathrm{g} / \mathrm{ml})$, or $9 \mathrm{~B}(0.5 \mu \mathrm{g} / \mathrm{ml})$ for $1 \mathrm{hr}$. The preincubation media were removed prior to assay for $\mathrm{Na}^{+}$uptake in response to $0.5 \mathrm{mM} \mathrm{CCh}$. Each value is the mean $\pm \mathrm{SEM}$ for triplicate samples, and these results are typical of two other similar experiments.

\begin{tabular}{llcc}
\hline $\begin{array}{c}\text { Growth } \\
\text { Conditons }\end{array}$ & $\begin{array}{c}\text { Pre-incubation } \\
\text { Conditions }\end{array}$ & \multicolumn{1}{c}{$\begin{array}{c}{ }^{22} \mathrm{Na}^{+} \\
\text {Uptake }\end{array}$} & $\begin{array}{c}\text { Uptake } \\
\text { into } \\
\text { Untreated } \\
\text { Cells }\end{array}$ \\
\hline Untreated & Control & $158 \pm 12$ & $\%$ \\
& $\alpha$-Bgt & $173 \pm 13$ & 100 \\
9B treated & $9 \mathrm{~B}$ & $148 \pm 4$ & 94 \\
& Control & $283 \pm 3$ & 179 \\
& $\alpha$-Bgt & $275 \pm 6$ & 174 \\
& $9 \mathrm{~B}$ & $301 \pm 23$ & 190 \\
\hline
\end{tabular}

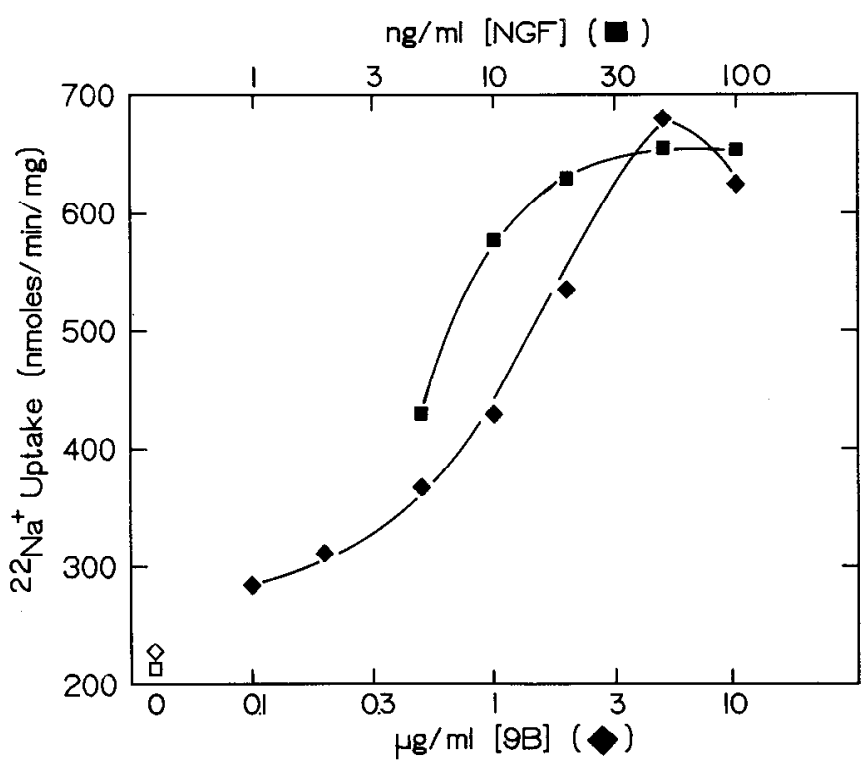

Figure 1. Effect of $9 \mathrm{~B}$ or $\beta-\mathrm{NGF}$ on ${ }^{22} \mathrm{Na}^{+}$uptake by $\mathrm{PC} 12$ cells. $\mathrm{PC} 12$ cells were plated in media containing fraction $9 \mathrm{~B}$ $(\diamond)$ at concentrations ranging from 0.1 to $10 \mu \mathrm{g} / \mathrm{ml}$ or $\beta$-NGF a) at concentrations of 5 to $100 \mathrm{ng} / \mathrm{ml}$. After 3 days, cells were replated for assay for $\mathrm{Na}^{+}$uptake with or without $3.2 \mathrm{mM} \mathrm{CCh}$ as described under "Materials and Methods." Each point represents toe average uptake in duplicate wells from which the values for each cell sample varied by less than $10 \%$. Protein content ranged from 270 to $440 \mu \mathrm{g}$ /well. The open symbols in each case represent data from control cells grown without growth factor in each experiment. These results are representative of results obtained in three separate experiments.

(fraction numbers $6,7,8,9 \mathrm{~A}$, and 10 as described by Hanley et al., 1977) were added to cells at a concentration of $1 \mathrm{mg} / \mathrm{ml}$ for $1 \mathrm{hr}$ prior to assay for $\mathrm{Na}^{+}$flux, we found no evidence for inhibition of CCh-stimulated $\mathrm{Na}^{+}$flux (data not shown).

We next compared the increased cholinergic sensitiv- ity of PC12 cells treated with different levels of $\beta$-NGF or $9 \mathrm{~B}$ for a total of 4 days with cells grown in normal growth medium (Fig. 1). Net $\mathrm{CCh}$-stimulated $\mathrm{Na}^{+}$uptake in cells exposed to either growth factor rose to a maximum level almost 3 times as great as in untreated cells. The maximum amount of CCh-stimulated ion flux was the same for each growth factor, but the amount of $9 \mathrm{~B}$ required to achieve these levels was 100 -fold greater than for $\beta$-NGF on a weight basis. A 4-day exposure to $0.2 \mu \mathrm{g}$ of fraction $9 \mathrm{~B} / \mathrm{ml}$ of medium produced discernible neurite outgrowth, while $5 \mathrm{ng} / \mathrm{ml}$ of $\beta$-NGF produced a similar response; maximum levels of growth factor-induced morphological change required $5 \mu \mathrm{g} / \mathrm{ml}$ of $9 \mathrm{~B}$ or $50 \mathrm{ng} / \mathrm{ml}$ of $\beta$-NGF.

Carbamylcholine concentrations of $3.2 \mathrm{~mm}$ were maximally effective in stimulating ${ }^{22} \mathrm{Na}^{+}$uptake into subconfluent cultures of $\mathrm{PC} 12$ cells grown under normal culture conditions or with either growth factor (Fig. 2). PC12 cells treated with $9 \mathrm{~B}$ or $\beta$-NGF for 5 days also showed increased $\mathrm{Na}^{+}$uptake in response to increasing concentrations of $\mathrm{CCh}$. Approximately the same low background level of $\mathrm{Na}^{+}$uptake was seen in untreated and growth factor-treated cells assayed without $\mathrm{CCh}$. Cells grown with either of the two growth factors or in control medium took up ${ }^{22} \mathrm{Na}^{+}$most rapidly with $3.2 \mathrm{mM} \mathrm{CCh}$; halfmaximal uptake occurred at 0.4 to $0.5 \mathrm{mM} \mathrm{CCh}$ in each case. $\mathrm{Na}^{+}$uptake by $\beta$-NGF- and 9B-treated cells assayed with maximally effective $\mathrm{CCh}$ concentrations increased by at least $100 \%$ compared to untreated cells assayed

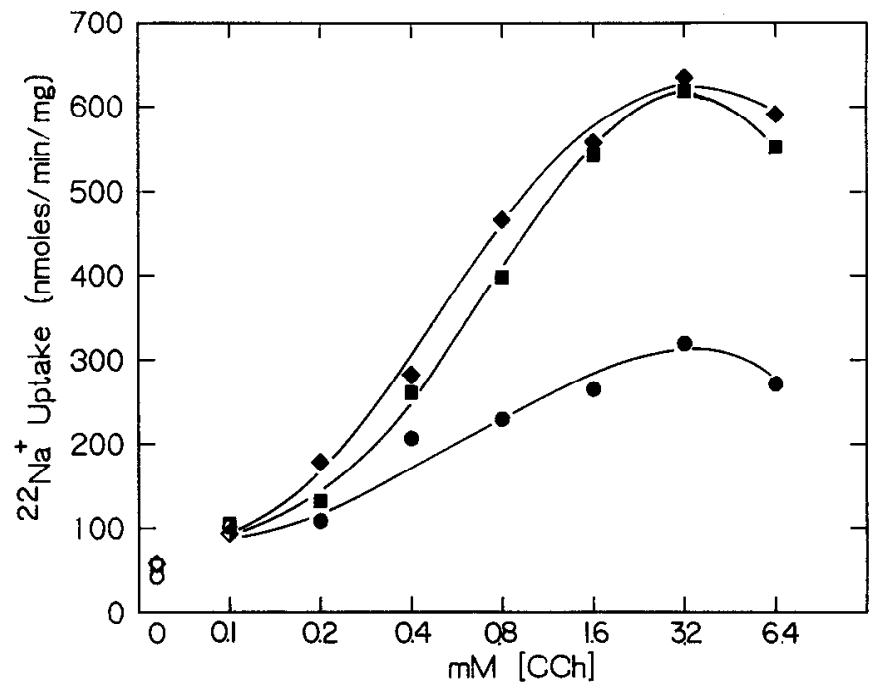

Figure 2. Carbamylcholine stimulation of $\mathrm{Na}^{+}$uptake in growth factor-treated and untreated cells. PC12 cells were grown in control medium (O) or in media containing $50 \mathrm{ng} / \mathrm{ml}$ of $\beta$-NGF $(\square)$ or $5 \mu \mathrm{g} / \mathrm{ml}$ of snake venom fraction $9 \mathrm{~B}(\bullet)$. After 2 days a second dose of fresh growth factor was added to the $\beta$ NGF- and 9B-treated cells. All cells were harvested after a total of 4 days and were replated on polylysine-coated dishes in media containing fresh growth factors. Duplicate cell samples were assayed for $\mathrm{Na}^{+}$uptake without agonist and with the indicated concentrations of $\mathrm{CCh}$. Uptake by individual cell samples was within $7 \%$ of each average uptake value for all assays with CCh concentrations greater than $0.4 \mathrm{mM}$ and within $20 \%$ of average uptake for the remaining samples; these results are typical of two such experiments. Protein concentration in individual wells ranged from 240 to $350 \mu \mathrm{g}$. 
under the same conditions, confirming that the morphological differentiation of PC12 cells in response to nerve growth factors was accompanied by an increase in $\mathrm{Na}^{+}$ uptake in response to the same maximally effective concentrations of $\mathrm{CCh}$.

Nicotinic stimulation of $\mathrm{Na}^{+}$uptake. The nicotinic cholinergic inhibitor $d$-tubocurarine (dTC) has been shown to inhibit CCh-stimulated $\mathrm{Na}^{+}$influx (Patrick and Stallcup, 1977b) as well as electrophysiological responses to iontophoretically applied acetylcholine (Dichter et al., 1977) in PC12 cells. Therefore, we examined the effect of dTC on the ${ }^{22} \mathrm{Na}^{+}$uptake into PC12 cells grown with and without each growth factor (Fig. 3A). Pre-incubation of cells with $400 \mu \mathrm{M}$ dTC for $10 \mathrm{~min}$ prior to assay inhibited more than $90 \%$ of the $\mathrm{Na}^{+}$uptake stimulated by CCh. Half-maximal inhibition of $\mathrm{Na}^{+}$flux occurred with 20 to $50 \mu \mathrm{M}$ dTC for growth factor-treated and untreated cells. In contrast, atropine, an inhibitor of muscarinic cholinergic responses, reduced $\mathrm{Na}^{+}$flux by less than $50 \%$ of control values in PC12 cells grown in each of the three media at the highest inhibitor concentration $(400 \mu \mathrm{M}$, Fig. $3 B)$.

We also examined the extent to which nicotine could mimic the effect of carbamylcholine in stimulating ${ }^{22} \mathrm{Na}^{+}$ influx. $\mathrm{Na}^{\prime}$ uptake by untreated and $9 \mathrm{~B}-$ or $\beta-\mathrm{NGF}$ treated cells (5-day total exposure) in response to nicotine concentrations ranging from 40 to $320 \mu \mathrm{M}$ was very similar to those results presented in Figure 1 for $\mathrm{CCh}$ stimulated uptake. Nicotine concentrations of $160 \mu \mathrm{M}$

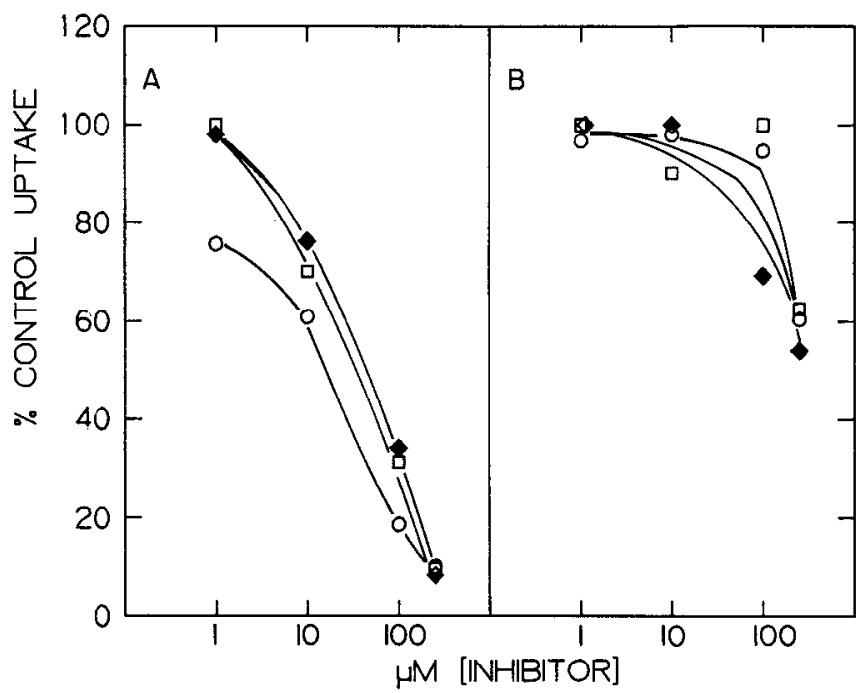

Figure 3. d-Tubocurarine and atropine inhibition of $\mathrm{Na}^{+}$ uptake by untreated, 9B-, and $\beta$-NGF-treated cells. PC1 2 cells plated on polylysine-coated 12 -well dishes were grown without (O) or with $5 \mu \mathrm{g} / \mathrm{ml}$ of $9 \mathrm{~B}(\bullet)$ or $50 \mathrm{ng} / \mathrm{ml}$ of $\beta-\mathrm{NGF}(\square)$ for 48 hr. Media were then removed and replaced with Prep medium containing $d$-tubocurarine $(A)$ or atropine $(B)$ at concentrations ranging from 1 to $400 \mu \mathrm{M}$ for $10 \mathrm{~min}$. The inhibitors were then removed, and the cells were assayed for ${ }^{22} \mathrm{Na}^{+}$uptake in response to a subsaturating concentration of $\mathrm{CCh}(1 \mathrm{mM})$. The results are expressed as the percentage of activity assayed without inhibitor for each growth condition: $206 \pm 2,346 \pm 13$, and $364 \pm 19 \mathrm{nmol} / \mathrm{min} / \mathrm{mg}$ of protein for untreated, $9 \mathrm{~B}$-, and $\beta$-NGF-treated cells, respectively, assayed in duplicate. A second experiment which included these inhibitors in the assay gave essentially the same results.
TABLE II

Nicotinic stimulation of $\mathrm{Na}^{+}$flux into $\mathrm{PC1} 2$ cells

CCh- and nicotine-stimulated $\mathrm{Na}^{+}$uptake by cells grown without added growth factor was compared to uptake by cells grown with $9 \mathrm{~B}$ or $\beta$-NGF for 4 days. Results are presented as the average of duplicate determinations from a single experiment and are compared as a percentage of uptake into control (untreated) cells assayed with either 3.2 $\mathrm{mM} \mathrm{CCh}$ or $160 \mu \mathrm{M}$ nicotine (Nic); nicotine-stimulated values are also expressed as a percentage of CCh-stimulated uptake into cells exposed to each growth factor.

\begin{tabular}{|c|c|c|c|c|c|}
\hline \multirow{3}{*}{$\begin{array}{c}\text { Growth } \\
\text { Media }\end{array}$} & \multicolumn{4}{|c|}{ Agonist } & \multirow[b]{3}{*}{$\begin{array}{l}\text { Uptake } \\
\text { into } \\
\text { CCh- } \\
\text { Stimu- } \\
\text { lated Cells }\end{array}$} \\
\hline & Nic & $\mathrm{CCh}$ & Nic & $\mathrm{CCh}$ & \\
\hline & \multicolumn{2}{|c|}{$\begin{array}{l}{ }^{22} \mathrm{Na}^{+} \\
\text {Uptake }\end{array}$} & \multicolumn{2}{|c|}{$\begin{array}{c}\text { Uptake } \\
\text { into } \\
\text { Untreated } \\
\text { Cells }\end{array}$} & \\
\hline & \multicolumn{2}{|c|}{$\mathrm{nmol} / \mathrm{min} / \mathrm{mg}$} & \multicolumn{2}{|c|}{$\%$} & $\%$ \\
\hline Control & 302 & 355 & 100 & 100 & 85 \\
\hline $9 \mathrm{~B}(5 \mu \mathrm{g} / \mathrm{ml})$ & 832 & 746 & 276 & 210 & 112 \\
\hline$\beta-\mathrm{NGF}(50 \mathrm{ng} / \mathrm{ml})$ & 844 & 852 & 280 & 240 & 99 \\
\hline
\end{tabular}

TABLE III

Effect of dbcAMP on CCh-stimulated $\mathrm{Na}^{+}$uptake with and without growth factors

Subconfluent cultures of $\mathrm{PCl} 2$ cells were replated on polylysinecoated dishes and exposed to the indicated concentrations of dbcAMP and/or growth factors for $24 \mathrm{hr}$ prior to assay for $\mathrm{Na}^{+}$uptake in response to $3.2 \mathrm{mM}$ carbamylcholine. Duplicate wells were assayed for each treatment condition, and these results are representative of two other similar experiments.

\begin{tabular}{|c|c|c|}
\hline & $\begin{array}{l}{ }^{22} \mathrm{Na}^{+} \\
\text {Uptake }\end{array}$ & $\begin{array}{c}\text { Uptake } \\
\text { into } \\
\text { Untreated } \\
\text { Cells }\end{array}$ \\
\hline & $\mathrm{nmol} / \mathrm{min} / \mathrm{mg}$ & $\%$ \\
\hline Untreated & $198 \pm 19$ & 100 \\
\hline dbcAMP (1 mM) & $184 \pm 1$ & 93 \\
\hline $9 \mathrm{~B}(5 \mu \mathrm{g} / \mathrm{ml})$ & $257 \pm 5$ & 130 \\
\hline$\beta$-NGF $(50 \mathrm{ng} / \mathrm{ml})$ & $284 \pm 14$ & 144 \\
\hline dbcAMP + 9B & $157 \pm 9$ & 80 \\
\hline $\mathrm{dbcAMP}+\beta-\mathrm{NGF}$ & $175 \pm 19$ & 89 \\
\hline $9 \mathrm{~B}+\beta-\mathrm{NGF}$ & $281 \pm 23$ & 142 \\
\hline
\end{tabular}

were maximally effective in stimulating $\mathrm{Na}^{+}$uptake by untreated cells and cells treated with either $\beta$-NGF or 9B. Table II presents a comparison of uptake by cells assayed with $160 \mu \mathrm{M}$ nicotine compared to uptake into cells from the same experiment assayed with $3.2 \mathrm{mM}$ $\mathrm{CCh}$. These results showed that the $\mathrm{Na}^{+}$influx induced by maximally effective doses of nicotine was approximately equal to the $\mathrm{Na}^{+}$uptake stimulated by $3.2 \mathrm{mM}$ CCh regardless of the growth conditions.

Cyclic AMP effect on CCh-stimulated $\mathrm{Na}^{+}$uptake. $\mathrm{N}^{6}$, $\mathrm{O}^{2 \prime}$-Dibutyryl cyclic AMP induces the outgrowth of short neurite-like processes from PC12 cells within $24 \mathrm{hr}$ (Schubert and Whitlock, 1978), and $\beta$-NGF plus dbcAMP greatly potentiates process formation compared to the response to either agent alone (Gunning et al., 1981b). We tested the possibility that dbcAMP would increase CCh-sensitive $\mathrm{Na}^{+}$uptake by $\mathrm{PC} 12$ cells or potentiate the effect of $\beta-\mathrm{NGF}$ or $9 \mathrm{~B}$. The results in Table III showed that the CCh-stimulated $\mathrm{Na}^{+}$influx into cells exposed to dbcAMP alone or with either growth 
factor was, in fact, less than into untreated cells. As noted by Gunning et al. (1981b), a high percentage of cells exposed to dbcAMP alone developed short processes, whereas the addition of dbcAMP to growth factortreated cells greatly enhanced process formation. The outgrowth of neurites from cells exposed to $\beta$-NGF or $9 \mathrm{~B}$ for $24 \mathrm{hr}$ was very sparse, even though these cells showed a definite increase in sensitivity to cholinergic stimulation (Table III). A combination of $9 \mathrm{~B}$ and $\beta$-NGF produced an increase in $\mathrm{Na}^{+}$flux approximately equal to $\beta$-NGF treatment alone; neurite outgrowth from such cells was essentially the same as from cells treated with either $9 \mathrm{~B}$ or $\beta$-NGF.

Time course of development of $\mathrm{CCh}$ sensitivity. We next compared $\mathrm{Na}^{+}$uptake in response to cholinergic stimulation by cells grown in normal culture medium with cells grown over the same period of time in media containing either $\beta$-NGF or $9 \mathrm{~B}$ added at approximately 12 hr intervals (Fig. 4). For cells assayed with $\mathrm{CCh}$, no increase in $\mathrm{Na}^{+}$uptake was detected until after $18 \mathrm{hr}$ of exposure to either $\beta$-NGF or $9 \mathrm{~B}$. After a 26 -hr exposure to either nerve growth factor, $\mathrm{Na}^{+}$influx into growth factor-treated cells increased by $40 \%$ compared to untreated cells. This enhanced sensitivity to CCh continued to increase gradually over most of the rest of the $90-\mathrm{hr}$ treatment period. The maximum increase of about 2 times the uptake level for untreated cells was reached after about 3 days' exposure to either growth factor.

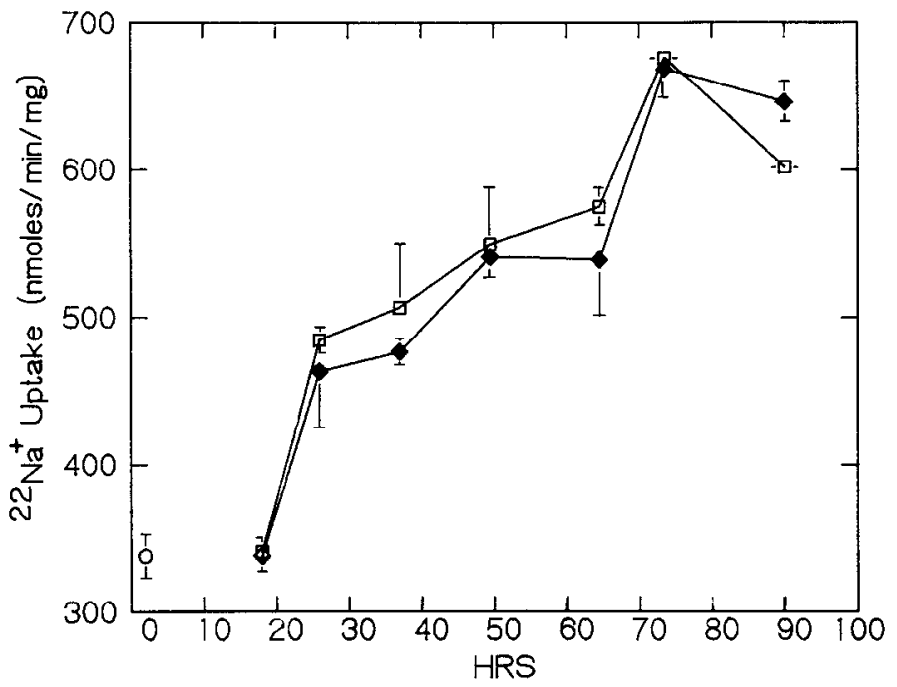

Figure 4. Sodium uptake into PC12 cells treated with $\beta$-NGF or $9 \mathrm{~B}$ for a total of 18 to $90 \mathrm{hr}$. A single dose of $\beta$-NGF (50 ng/ $\mathrm{ml})$ or $9 \mathrm{~B}(5 \mu \mathrm{g} / \mathrm{ml})$ was added to one group of dishes at the time they were replated and to other dishes of cells at intervals thereafter. Seventy-two hours after the first cells were exposed to growth factor, all cell cultures were replated for assay of $\mathrm{Na}^{+}$ uptake in response to $3.2 \mathrm{mM} \mathrm{CCh}$ as described under "Materials and Methods." Fresh growth factors were added to all previously treated cells at that time as well as to previously untreated cells for the final 18 -hr period prior to assay. Results are expressed as nanomoles of $\mathrm{Na}^{+}$taken up by untreated $(\mathrm{O})$ cells grown for the entire 90 -hr period as well as for cells treated with $9 \mathrm{~B}(-)$ and $\beta$-NGF ( $\square$ ) for varying lengths of time before the assay. The error bars indicate the range of duplicate cell samples in this experiment; three other experiments of this type gave similar results.
TABLE IV

Stability of growth factor-enhanced $\mathrm{CCh}$-stimulaled $\mathrm{Na}^{+}$uplake

Freshly subcultured PC12 cells were grown in media without growth factor or with $5 \mu \mathrm{g} / \mathrm{ml}$ of $9 \mathrm{~B}$ or $50 \mathrm{ng} / \mathrm{ml}$ of $\beta$-NGF for 4 days, then replated in fresh media either with or without growth factors for an additional 3-day period. Finally, cells were harvested and replated in media with or without growth factor on polylysine-coated dishes for assay of $\mathrm{Na}^{+}$uptake 1 day later. Cells were washed three times with 15 $\mathrm{ml}$ of Prep medium before transfer from nerve growth factor-containing to control (Con) growth medium. Results are expressed as a percentage of uptake into cells (assayed in duplicate wells) treated with $9 \mathrm{~B}$ or $\beta$ NGF for the entire length of the experiment minus the uptake by cells grown for the same period in control medium. Essentially the same results were obtained when this experiment was repeated.

\begin{tabular}{|c|c|c|c|c|}
\hline \multicolumn{3}{|c|}{ Growth Media } & \multirow{2}{*}{$\begin{array}{l}{ }^{22} \mathrm{Na}^{+} \\
\text {Uptake }\end{array}$} & \multirow{2}{*}{$\begin{array}{c}\text { Growth } \\
\text { Factor- } \\
\text { enhanced } \\
\text { Uptake }\end{array}$} \\
\hline Days 1-4 & Days 5-7 & Day 8 & & \\
\hline & & & $\mathrm{nmol} / \mathrm{min} / \mathrm{mg}$ & $\%$ \\
\hline Con & Con & Con & $206 \pm 20$ & 0 \\
\hline Con & $9 \mathrm{~B}$ & $9 \mathrm{~B}$ & $440 \pm 14$ & 75 \\
\hline $9 \mathrm{~B}$ & $9 \mathrm{~B}$ & $9 \mathrm{~B}$ & $519 \pm 40$ & 100 \\
\hline $9 \mathrm{~B}$ & $9 B$ & Con & $450 \pm 13$ & 78 \\
\hline $9 \mathrm{~B}$ & Con & Con & $286 \pm 9$ & 26 \\
\hline Con & NGF & NGF & $351 \pm 18$ & 73 \\
\hline $\mathrm{NGF}$ & NGF & NGF & $410 \pm 36$ & 100 \\
\hline $\mathrm{NGF}$ & NGF & Con & $358 \pm 1$ & 75 \\
\hline $\mathrm{NGF}$ & Con & Con & $290 \pm 23$ & 42 \\
\hline
\end{tabular}

Other experiments (not shown) compared the $\mathrm{Na}^{+}$ taken up by cells plated at the same time with or without growth factor, then assayed on successive days. The results from these experiments showed that the $\mathrm{CCh}$ sensitive $\mathrm{Na}^{+}$uptake into untreated cells remained unchanged for 4 days, whereas 9B- or $\beta$-NGF-treated cells showed increased sensitivity to $\mathrm{CCh}$ which was similar to the results of the experiment shown in Figure 4.

Nerve growth factor-enhanced CCh sensitivity slowly decreased after growth factor-treated PC12 cells were replated in normal growth medium (Table IV). As expected, cells exposed to optimal levels of NGFs throughout the 8-day experiment showed the highest levels of CCh-stimulated $\mathrm{Na}^{+}$uptake. Cells exposed to $\beta$-NGF or $9 \mathrm{~B}$ for only the final 4 days of this period had $\mathrm{Na}^{+}$uptake rates equal to about $75 \%$ of the maximum level. Also, the CCh-sensitive $\mathrm{Na}^{+}$flux was reduced from the maximum level by about the same amount $(25 \%)$ when cells were grown for 7 days with NGFs, then 1 day without. Roughly one-third of the maximum response remained when growth factors were removed during the final 4 days of the experiment.

\section{Discussion}

These results demonstrate that nerve growth factors from two different sources dramatically enhance the flux of $\mathrm{Na}^{+}$through the nicotinic acetylcholine receptorlinked ion channels in PC12 cells. Cells grown in normal medium took up $\mathrm{Na}^{+}$in response to cholinergic stimulation, but the rate of this uptake did not change during the 4- to 8-day duration of these experiments. The passive flux of ions through these channels during the first $30 \mathrm{sec}$ after the addition of optimal concentrations of cholinergic agonists was virtually identical whether stimulated by nicotine or carbamylcholine. Uptake was in- 
hibited to the same extent by the nicotinic cholinergic antagonist $d$-tubocurarine whether the cells were grown with or without either NGF. These results suggest that NGF treatment increases the number of functional ion conductance channels in NGF-treated cells over a period of several days rather than changing the pharmacological characteristics of the receptors themselves.

Dichter et al. (1977) first showed that $\beta$-NGF increased membrane conductance in $\mathrm{PC} 12$ cells in response to $\mathrm{ACh}$ by measuring the depolarization of individual impaled cells grown for 2 weeks with NGF. In contrast, our experiments focused on changes in $\mathrm{ACh}$-sensitive $\mathrm{Na}^{+}$ ion conductance changes in cells treated with NGFs at intervals over a period of several days, and we measured ion conductance in whole populations of $\mathrm{PC} 12$ cells. Our results showed that $\mathrm{Na}^{+}$flux into cells increased between 1 and 4 to 6 days after the addition of nerve growth factors. Thus, these changes occurred prior to the cessation of cell division and DNA synthesis in response to NGF and roughly coincided with the increased RNA and protein content of PC12 cells treated with NGF described by Gunning et al. (1981a).

Burstein and Greene (1978) showed that RNA synthesis inhibitors prevented neurite outgrowth but not neurite regeneration. However, when PC12 cells were treated with low levels of the RNA synthesis inhibitor actinomycin D $(0.01 \mu \mathrm{g} / \mathrm{ml}) 30 \mathrm{hr}$ before they were assayed for $\mathrm{Na}^{+}$uptake, CCh-stimulated ion flux into both NGFtreated and untreated cells was inhibited (C. Amy, unpublished results). Therefore, we were unable to determine whether RNA synthesis was required for the increased sensitivity of PC12 cells to cholinergic agents using this inhibitor.

NGFs induce an increased sensitivity to cholinergic agonists so that ${ }^{22} \mathrm{Na}^{+}$uptake per mg of protein was 2 to 3 times the level in untreated cells after 4 to 6 days. Since cells extend long neuritic processes in response to nerve growth factors, we chose to normalize uptake into cells grown under different conditions on the basis of protein content for the following reasons. Over the 4- or 6 -day periods of growth factor treatment, control and NGF-treated cultures increase in cell number at approximatcly the same rate as shown by our unpublished observations and results from other studies (Greene and Tischler, 1976; Gunning et al., 1981a). However, Gunning et al. (1981a) showed that the protein to DNA ratio in cells gradually increased following NGF addition so that protein content per cell was about $50 \%$ greater than control sister cultures after 5 days' exposure to NGF. Thus, comparing $\mathrm{Na}^{+}$uptake values based on protein content more accurately reflects changes in cell size (and surface area) than would normalizing uptake on the basis of cell number. These factors suggest that an increase in the density of $\mathrm{ACh}$ receptors on the surface of NGFtreated cells is responsible for the increased uptake observed and that this change cannot be accounted for by an increase in cell surface area with the same density of receptor-linked channels as untreated cells.

In all time course experiments, cells were replated in fresh media with fresh growth factor 18 to $24 \mathrm{hr}$ before assay for $\mathrm{Na}^{+}$flux to assure that the cells grown in different media were assayed under more nearly comparable conditions. PC12 cells subcultured on the same day, grown in media without NGFs, assayed on 4 successive days took up $\mathrm{Na}^{+}$at the same initial rate. Thus, the rate of ${ }^{22} \mathrm{Na}^{+}$uptake did not increase merely as a consequence of growth conditioning of the medium or because of increased cell density with age. Also, when neurites were lost from cells replated in media without NGF, cholinergic sensitivity was maintained to a great extent for at least $24 \mathrm{hr}$.

The generation of neurite-like processes by dbcAMP alone or in combination with either growth factor was not associated with increased sensitivity to cholinergic stimulation of sodium flux. These results suggest that dbcAMP does not mediate the NGF-induced changes in ion conductance described in this study.

Jumblatt and Tischler (1982) recently showed that PC12 cells possess high affinity binding sites for the muscarinic antagonist quinuclidinyl benzilate (QNB). $\beta$ $\mathrm{NGF}$ increased the number of QNB binding sites on cells after a 2- to 5-day treatment period; maximum binding was seen after about 2 weeks. Also, the muscarinic antagonist atropine was a much better inhibitor of QNB binding than was $d$-tubocurarine. Our results showed that nicotine was as effective as carbamylcholine in stimulating $\mathrm{Na}^{+}$uptake by NGF-treated or untreated cells (Table II) and that $\mathrm{Na}^{+}$uptake was much more sensitive to dTC than to atropine inhibition (Fig. 3). The effects of these two inhibitors were the same whether cells pre-incubated with inhibitor were assayed for $\mathrm{Na}^{+}$ uptake with or without inhibitor. Thus, although the increase in muscarinic binding sites described by Jumblatt and Tischler (1982) was induced by growth conditions similar to those which enhanced $\mathrm{Na}^{+}$uptake in the present study, the time required for these effects and the inhibitor sensitivity differences clearly showed that increased $\mathrm{Na}^{+}$uptake was not due to an increase in the number of QNB binding sites.

\section{References}

Burstein, D. E., and L. A. Greene (1978) Evidence for RNA synthesis dependent and independent pathways in stimulation of neurite outgrowth by nerve growth factor. Proc. Natl. Acad. Sci. U. S. A. 75: 6059-6063.

Dichter, M. A., A. S. Tischler, and L. A. Greene (1977) Nerve growth factor induced increase in electrical excitability and acetylcholine sensitivity of a rat pheochromocytoma cell line. Nature 268: 501-504.

Garrels, J. I., and D. Schubert (1979) Modulation of protein synthesis by nerve growth factor. J. Biol. Chem. 254: 79787985.

Greene, L. A., and A. Rukenstein (1981) Regulation of acetylcholinesterase activity by nerve growth factor. J. Biol. Chem. 256: $6363-6367$.

Greene, L. A., and A. S. Tischler (1976) Establishment of a noradrenergic clonal line of rat adrenal pheochromocytoma cells which respond to nerve growth factor. Proc. Natl. Acad. Sci. U. S. A. 73: 2424-2428.

Gunning, P. W., G. E. Landreth, P. Layer, M. Ignatius, and E. M. Shooter (1981a) Nerve growth factor-induced differentiation of PC12 cells: Evaluation of changes in RNA and DNA metabolism. J. Neurosci. 1: 368-379.

Gunning, P. W., G. E. Landreth, M. A. Bothwell, and E. M. Shooter (1981b) Differential and synergistic actions of nerve growth factor and cyclic AMP in PC12 cells. J. Cell Biol. 89: $240-245$.

Hanley, M. (1978) Biochemistry of snake venom neurotoxins 
and their application to the study of the synapse. Doctoral thesis, University of California, Berkeley.

Hanley, M. R., V. A. Eterovic, S. P. Hawkes, A. J. Hebert, and E. L. Bennett (1977) Neurotoxins of Bungarus multicinctus venom. Purification and partial characterization. Biochemistry 16: $5840-5849$.

Hatanaka, H., U. Otten, and H. Thoenen (1978) Nerve growth factor-mediated selective induction of ornithine decarboxylase in rat pheochromocytoma; a cyclic AMP-independent process. FEBS Lett. 92: 313-316.

Jumblatt, J. E., and A. S. Tischler (1982) Regulation of muscarinic ligand binding sites by nerve growth factor in $\mathrm{PC} 12$ pheochromocytoma cells. Nature 297: 152-154.

Karpen, J. W., H. Aoshima, L. G. Abood, and G. P. Hess (1982) Cocaine and phencyclidine inhibition of the acetylcholine receptor: Analysis of the mechanisms of action based on measurements of ion flux in the millisecond-to-minute time region. Proc. Natl. Acad. Sci. U. S. A. 79: 2509-2513.
Lowry, O. H., N. J. Rosebrough, A. L. Farr, and R. J. Randall (1951) Protein measurement with the Folin phenol reagent. J. Biol. Chem. 193: 265-275.

Patrick, J., and W. Stallcup (1977a) Immunological distinction between acetylcholine receptor and the $\alpha$-bungarotoxin-binding component on sympathetic neurons. Proc. Natl. Acad. Sci. U. S. A. 74: 4689 4692.

Patrick, J., and W. Stallcup (1977b) $\alpha$-Bungarotoxin binding and cholinergic receptor function on a rat sympathetic nerve line. J. Biol. Chem. 252: 8629-8633.

Schubert, D., and C. Whitlock (1978) Alteration of cellular adhesion by nerve growth factor. Proc. Natl. Acad. Sci. U. S. A. 74: $4055-4058$.

Schubert, D., S. Heinemann, and Y. Kidororo (1977) Cholinergic metabolism and synapse formation by a rat nerve cell line. Proc. Natl. Acad. Sci. U. S. A. 74: 2579-2583.

Stallcup, W. B. (1979) Sodium and calcium fluxes in a clonal nerve cell line. J. Physiol. (Lond.) 286: 525-540. 